\title{
PIERWSZE LATA ARCHIWUM UNIWERSYTETU KARDYNALA STEFANA WYSZYŃSKIEGO W WARSZAWIE - ORGANIZACJA \\ I FUNKCJONOWANIE
}

Akademia Teologii Katolickiej w Warszawie, utworzona w 1954 r. na bazie Wydziału Teologii Katolickiej, wyłączonego ze struktur Uniwersytetu Warszawskiego oraz Wydziału Teologicznego Uniwersytetu Jagiellońskiego, przez cały okres swego istnienia (1954-1999) nie posiadała archiwum. Fakt ten należy tłumaczyć przede wszystkim tym, iż ATK była uczelnią małą. Do 1987 r. tworzyły ja jedynie trzy wydziały, powstałe z katedr Wydziału Teologii Katolickiej UW, a mianowicie: Wydział Teologiczny, Wydział Filozofii Chrześcijańskiej i Wydział Prawa Kanonicznego. Rozwój uczelni był celowo hamowany przez Ministerstwo Szkolnictwa Wyższego i Techniki, określające limity studentów na poszczególne kierunkina niskim poziomie ${ }^{2}$. Taka sytuacja spowodowała, iż przyrostaktbyłwATK stosunkowo niewielki i nie widziano potrzeby utworzenia archiwum jako odrębnej jednostki. Poszczególne jednostki organizacyjne przechowywały wytworzone przez siebie akta we własnych registraturach, zaś akta ogólnouczelniane i personalne znalazły swe miejsce w szafach sekretariatu rektora ${ }^{3}$. Analogicznie też, wszelkie czynności, należące do archiwum - jak choćby rewindykacja akt - wy-

* Dariusz Milewski - dr historii, adiunkt w Instytucie Nauk Historycznych Uniwersytetu Kardynała Stefana Wyszyńskiego.

${ }^{1}$ Niniejszy artykuł jest zmodyfikowaną wersją referatu Miejsce Archiwum w strukturze Uniwersytetu Kardynała Stefana Wyszyńskiego w Warszawie - organizacja i funkcjonowanie, wygłoszonego w czasie X konferencji Sekcji Archiwów Szkół Wyższych i Instytucji Naukowych SAP Archiwum jako wizytówka macierzystej instytucji, zorganizowanej przez Archiwum UAM w Poznaniu w 2004 r

${ }^{2}$ Przykładowo w 1971 r. na ATK studiowało zaledwie 1374 studentów, w 1990 r. - 2774, a w 1998 r. - 8901. Zob. J. Mandziuk, Dzieje Akademii Teologii Katolickiej w Warszawie 1954-1999, Warszawa 1999, s. 24, 68.

${ }^{3}$ Zob. Archiwum UKSW (dalej: AUKSW), protokół zdawczo-odbiorczy z dnia 28 XII 1972 r. akta rektora, teczka „Archiwum”. W zakres obowiazków M. Debowskiej, określonych 27 X 1972 r., pełniącej funkcję zastępcy kierownika działu w sekretariacie rektora, wchodziło m.in. ,prowadzenie archiwum akt personalnych" (AUKSW, akta osobowe M. Dębowskiej, sygn. DK-I/114). 
konywane były przez te jednostki organizacyjne, których dana sprawa dotyczyła. Wymieńmy tu dla przykładu sprawę zwrotu części akt Uniwersytetowi Jagiellońskiemu, która latem 1958 r. przeprowadziła kierownik Samodzielnej Sekcji Toku Studiów i Planowania ATK, Jadwiga Kosk. W jej aktach personalnych znajdujemy polecenie, wydane 24 lipca $1958 \mathrm{r}$. przez dyrektora administracyjnego ATK Wacława Łapińskiego, w którym czytamy m.in.: „W związku z koniecznościa przekazania przez Samodzielna Sekcje Toku Studiów i Planowania archiwum akt należących do UJ w Krakowie, ATK poleca Obywatelce udać się w dniu 25 bm. na Dworzec Główny-Towarowy w celu załatwienia formalności związanych z wyekspediowaniem do Krakowa trzech skrzyń z tymi aktami, które na godz. 10.00 rano zostaną dostarczone na dworzec przez obywatela Wyszomirskiego"4. Także w 1988 r., kiedy ATK wysyłała do Archiwum UJ kolejną partię materiałów, wytworzonych na Wydziale Teologicznym UJ, sprawą kierował ówczesny dyrektor administracyjny ATK, Władysław Dziedziak ${ }^{5}$. Tenże dyrektor administracyjny wynegocjował w 1977 r. warunki porozumienia z Archiwum UW, na podstawie którego miano przekazać do Archiwum UW akta spraw zakończonych na Uniwersytecie Warszawskim, a znajdujące się do tej pory w ATK - sprawą miała zająć się wymieniona wyżej Jadwiga Kosk. Ponieważ ATK zwlekało z wykonaniem tego porozumienia, rzecz doszła do skutku dopiero w sierpniu 1988 r. Akta ogólnouczelniane zostały wtedy przekazane przez Sekcję Toku Studiów i Planowania ${ }^{6}$ Rok później, we wrześniu 1989 r., do Archiwum UW przekazane zostały prace magisterskie i doktorskie, napisane na Wydziale Teologii Katolickiej UW - tym razem jednostką przekazującą akta była Biblioteka ATK, gromadząca aż po dzień dzisiejszy wtórniki prac dyplomowych, bronionych na uczelni?

Jak widać $\mathrm{z}$ powyższego, ATK przez długi czas doskonale radziła sobie bez archiwum. Sytuacja uległa jednak pogorszeniu w latach 90., kiedy po upadku komunizmu i sztucznych ograniczeń w naborze studentów, uczelnia zaczęła się gwałtownie rozrastać. Zwiększonemu przyrostowi akt, nie hamowanemu przez brakowanie materiałów niearchiwalnych - którego po prostu nie miał kto przeprowadzić - nie mogły sprostać szafy w registraturach. Akta zaczęto więc gromadzić w szafach na korytarzach, w końcu zaś znaleziono niewielkie pomieszczenie, które szybko zapełniono, głównie aktami studenckimi. Oczywiście nie było mowy o jakimkolwiek uporządkowaniu czy opracowaniu narastającego zasobu, co dotyczyło zwłaszcza akt ogólnych. Dalsze utrzymywanie takiego stanu rzeczy prowadziło nieomylnie do sytuacji, w której nikt w ATK nie wiedział, gdzie i co się znajduje. Nic dziwnego zatem, iż kontrola zasobu archiwalnego, przeprowadzona przez Archiwum Państwowe m.st. Warszawy we wrześniu 1999 r., w związku ze staraniami o przekształcenie ATK w Uniwersytet Kardynała Stefana Wy-

\footnotetext{
${ }^{4}$ AUKSW, akta osobowe J. Kosk, sygn. DK-I/349.

${ }^{5}$ Zob. W. Dziedziak do Archiwum UJ, Warszawa, 2 VIII 1988 r., AUKSW, akta rektora, teczka "Archiwum".

${ }^{6}$ Protokół zdawczo-odbiorczy przekazania akt do Archiwum UW z dnia 11 VIII 1988 r., Tamże.

${ }^{7}$ Protokół zdawczo-odbiorczy przekazania prac magisterskich i doktorskich do Archiwum UW
} z dnia 7 IX 1989 r., Tamże. szyńskiego, przyniosła jedno generalne zalecenie: jak najszybsze utworzenie archiwum jako odrębnej jednostki organizacyjnej w ramach uczelni.

Kontrola ta przyniosła wreszcie długo oczekiwany przełom w kwestii archiwizacji akt Akademii Teologii Katolickiej, dajac władzom uczelni niezbędny impuls do zorganizowania archiwum. Zgodnie ze Statutem ATK, archiwum miało być złaczone z Biblioteka, jednakże z chwila przekształcenia uczelni w UKSW powstała dogodna sposobność do utworzenia archiwum jako odrebnej jednostki organizacyjnej. Na początek należało przeprowadzić ocenę archiwalną akt, wybrakować materiały niearchiwalne i zgromadzić cały zasób archiwalny w jednym pomieszczeniu, scalając akta rozproszone po poszczególnych komórkach organizacyjnych. Zadanie to spoczęło w znacznej mierze na barkach dyrektora Biblioteki UKSW, Piotra Latawca, zgodnie ze Statutem ATK odpowiedzialnego za sprawy archiwizacji akt. Porozumiał sie on z dyrektorem Archiwum UW, Krzysztofem Pileckim, który podjął się przeprowadzenia oceny archiwalnej akt UKSW. Ponieważ Uniwersytet musiał mieć własnego archiwistę, w grudniu 1999 r. zatrudniono na to stanowisko Dariusza Milewskiego, poczatkowo na umowe-zlecenie, z zadaniem uporządkowania dokumentacji archiwalnej UKSW. Trzyosobowa komisja, złożona z wyżej wymienionych, przeprowadziła w grudniu 1999 r. ocenę archiwalna akt i zakwalifikowała do wybrakowania około $79 \mathrm{mb}$ akt kategorii od $\mathrm{B}_{\mathrm{c}}$ do $\mathrm{B}_{5}$. Były wśród nich m.in. raporty dzienne stołówki ATK, karty magazynowe ewidencji ilościowej, raporty kasowe, dowody księgowe i itp. materiały niearchiwalne, które zajmowały miejsce w szafach różnych registratur jeszcze od połowy lat $60 .{ }^{8}$ Dodajmy, że - zgodnie z utrwaloną tradycja ATK - całość prac archiwizacyjnych nadzorował ówczesny dyrektor administracyjny UKSW, Andrzej Grochowski.

Szczéśliwie dla nowo powstajacego Archiwum, jesienia 1999 r. oddano do użytku tzw. nowy gmach Uniwersytetu, do którego przeniesiono Bibliotekę. Dzieki temu dotychczasowy magazyn Biblioteki, o powierzchni $78 \mathrm{~m}^{2}$, zostal przekazany na magazyn Archiwum. Aż do końca 2001 r. spełniał on jednocześnie funkcje pomieszczenia biurowego, poniewaź Uniwersytet $w$ dalszym ciągu borykał sie z trudnościami lokalowymi. Tymczasem podjeto prace legislacyjne, majace unormować status prawny Archiwum i określić jego miejsce w strukturze uczelni tudzież wprowadzić w życie bezdziennikowy system kancelaryjny. W dniu 15 grudnia 1999 r. rektor UKSW, ks. prof. Roman Bartnicki, podpisał zarzadzenie określajace zakres działania rektora i prorektorów, które podporzadkowało - notabene jeszcze oficjalnie nie istniejące - Archiwum UKSW prorektorowi ds. rozwoju i współpracy. Artykuł 7. tegoż zarządzenia głosił: ,Zakres działań prorektora do spraw rozwoju i współpracy obejmuje [...] sprawy archiwizowania materiałów”, zaś artykuł 8.: „W bezpośrednim nadzorze prorektora do spraw rozwoju i współpracy pozostaje: [...] Archiwum"". Zapis ten był wyrazem koncepcji nadania projektowanemu Archiwum rangi jednostki pozawydziałowej, co wiąza-

${ }^{8}$ Zob. Protokół brakowania akt UKSW z 21 XII 1999 r., AUKSW, Wydzielanie akt na makulaturę, akta bieżące, sprawa nr AUKSW-732-1/99.

${ }^{9}$ Zarządzenie nr 4/99/U Rektora Uniwersytetu Kardynała Stefana Wyszyńskiego w Warszawie z dnia 15 grudnia 1999 r. w sprawie określenia szczegółowego zakresu działania Rektora 
ło się z ogólnouczelnianym zakresem działania Archiwum i jego uprawnieniami do wizytowania wszystkich jednostek organizacyjnych i sprawowania kontroli postępowania $\mathrm{z}$ dokumentacja. Myśl ta znalazła potwierdzenie w opracowanej na początku $2000 \mathrm{r}$. Instrukcji archiwalnej, zatwierdzonej przez dyrektora Archiwum Państwowego m.st. Warszawy Ryszarda Wojtkowskiego pismem z dnia 31 marca 2000 r. Według § 2 pkt 1 tejże Instrukcji: „Zgodnie ze strukturą organizacyjną UKSW Archiwum jest jednostką pozawydziałową i podlega bezpośrednio jednemu z Prorektorów uczelni”. Wspomniana Instrukcja archiwalna wraz z Instrukcją kancelaryjną i Wykazem akt weszła w życie 1 października 2000 r. na mocy Zarzadzenia nr 7/2000 Rektora UKSW z dnia 1 września 2000 r. To samo zarządzenie powoływało do życia Archiwum uczelni: „Na podstawie art. 35 ustawy z dnia 14 lipca 1983 r. o narodowym zasobie archiwalnym i archiwach (Dz.U. $1983 \mathrm{nr}$ 83, poz. 173) tworzę Archiwum UKSW jako jednostkę pozawydziałową podległą Prorektorowi ds. Rozwoju i Współpracy"10.

$\mathrm{Z}$ dniem 1 października 2000 r. funkcjonujące dotąd nieformalnie Archiwum UKSW znalazło wreszcie swoje umocowanie prawne w strukturze Uniwersytetu. Dysponowało ono jednym lokalem, którym był wymieniony wcześniej były magazyn Biblioteki i zatrudniało dwóch pracowników na pełnych etatach asystenta dokumentacji $\mathrm{i}$ informacji naukowej oraz młodszego dokumentalisty. Bieżąca działalność Archiwum szła wtedy w dwóch kierunkach: porządkowania posiadanego już zasobu i przejmowania akt z poszczególnych jednostek organizacyjnych UKSW oraz dopełnienia regulacji prawnych, określających funkcjonowanie Archiwum. We współpracy z ówczesnym prorektorem ds. rozwoju i współpracy UKSW, prof. Zygmuntem Niewiadomskim, przygotowano - wzorowane na analogicznych dokumentach Archiwum UW - Regulamin Archiwum oraz Regulamin udostepniania zasobu Archiwum UKSW, które zostały podpisane przez rektora UKSW w dniu 6 listopada 2001 r. ${ }^{11}$ Regulamin Archiwum UKSW potwierdzał funkcjonowanie Archiwum jako jednostki pozawydziałowej Uniwersytetu, wchodzacej w skład systemu dokumentacji i informacji naukowej Uniwersytetu, a jednocześnie bedacej ogniwem państwowej sieci archiwalnej (§ 1 pkt 1). Jako dokumenty regulujące działalność Archiwum ustalone zostały: Statut UKSW, Regulamin organizacyjny UKSW, Instrukcja kancelaryjna, Rzeczowy wykaz akt i Instrukcja archiwalna UKSW oraz sam regulamin Archiwum (§ 1 pkt 2). W dalszej

i Prorektorów, w: Kroniki Uniwersytetu Kardynała Stefana Wyszyńskiego w Warszawie, red. H. J. Kaczmarski, nr 1-2/2000, Warszawa 2000, 259-260.

${ }^{10}$ Zarzadzenie nr 7/2000 Rektora Uniwersytetu Kardynała Stefana Wyszyńskiego w Warszawie $\mathrm{z}$ dnia 1 września $2000 \mathrm{r}$. w sprawie utworzenia Archiwum Uniwersytetu oraz wprowadzenia w życie norm kancelaryjnych i podstawowych dokumentów, regulujących obieg akt uczelni, AUKSW, Organizacja jednostek pozawydziałowych - Archiwum, akta bieżace, sprawa nr AUKSW-01211/2000. Zarzadzenie to wraz z obiema Instrukcjami wydrukowane zostało w: Kroniki Uniwersytetu, nr 3/2000, Warszawa 2001, s. 80-99.

11 Regulamin Archiwum Uniwersytetu Kardynała Stefana Wyszyńskiego w Warszawie, AUKSW, Organizacja jednostek pozawydziałowych - Archiwum, akta bieżące, sprawa nr AUKSW0121-1/01 i Regulamin udostepniania zasobu Archiwum Uniwersytetu Kardynała Stefana Wyszyńskiego w Warszawie, Tamże, sprawa nr AUKSW-0121-2/01. kolejności stwierdzono, że „nadzór ogólny nad Archiwum sprawują Senat i Rektor Uniwersytetu” (§2 pkt 1), zaś „Archiwum podlega bezpośrednio jednemu z Prorektorów Uniwersytetu" ( $\$ 2$ pkt 2). Jako podstawowe zadania Archiwum wymieniono: ,gromadzenie, ewidencjonowanie, przechowywanie, opracowanie i udostepnianie materiałów archiwalnych, wchodzacych w skład zasobu Archiwum, działalność informacyjna oraz prace badawcze i wydawnicze związane z dziejami nauki" (§ 3). Warto zwrócić uwage zwłaszcza na zapis o działalności naukowobadawczej Archiwum, dajacy mu możliwość wykroczenia poza funkcje właściwe dla składnicy akt i podnoszący rangę Archiwum w Uniwersytecie. Podobną możliwość otwiera, wyrażony expressis verbis zapis o współpracy Archiwum z archiwami państwowymi oraz archiwami szkół wyższych w kraju i za granicą w zakresie działalności archiwalnej (§ 9).

Pełne wykorzystanie możliwości pracy na niwie naukowej, jakie otworzyły przed pracownikami Archiwum korzystne zapisy w Regulaminie Archiwum UKSW, wymagało jednak przeznaczenia na ten cel przede wszystkim czasu, potrzebnego na uporządkowanie zasobu archiwalnego, który mógłby stać się bazą źródłową dla badań historycznych. Tymczasem czasu tego w pierwszych latach działalności Archiwum brakowało. Można wyobrazić sobie, jak czasochłonne było odrobienie zaległości, sięgających 1954 r. Dotyczyły one zarówno materiałów już przechowywanych w Archiwum, jak i sposobu prowadzenia dokumentacji bieżącej w registraturach. Stad u progu swej działalności Archiwum dało się poznać uczelni jako inicjator i promotor wdrażania bezdziennikowego systemu kancelaryjnego. Jeszcze w lutym 2000 r. zorganizowano szkolenie pracowników administracji, które przeprowadził dyrektor Archiwum UW, Krzysztof Pilecki. Przezwyciężenie starych nawyków nie było jednak łatwym zadaniem, tak iż na początku września 2001 r. stwierdzono, iż nowy system kancelaryjny, oficjalnie obowiązujący od 1 października 2000 r., de facto w ogóle nie jest stosowany. Archiwum UKSW zwróciło sie w tej sprawie do prorektora ds. rozwoju i współpracy, który przekazał rzecz dyrektorowi administracyjnemu. Tenże pismem okólnym z dnia 17 września 2001 r. przypomniał o konieczności stosowania systemu bezdziennikowego, a zarazem wprowadził w życie wykaz oznaczeń literowych poszczególnych jednostek i komórek organizacyjnych UKSW, przygotowany przez Archiwum ${ }^{12}$. W ślad za tym, w dniu 15 października 2001 r. dyrektor administracyjny zarzadził przeprowadzenie powtórnego szkolenia, które odbyło sie w dwóch turach w dniach 19 i 23 października 2001 r. $^{13}$

Kiedy po przeprowadzonych szkoleniach zaczęto wreszcie wcielać w życie bezdziennikowy system kancelaryjny, okazało sie, że obowiazujacy Wykaz akt jest niewystarczający i należy go zmodyfikować. Nowy wykaz zatwierdzony został przez dyrektora Archiwum Państwowego m.st. Warszawy Ryszarda Wojtkowskiego w dniu 10 stycznia 2002 r. i wprowadzony został w życie zarządzeniem 101 .

${ }^{12}$ AUKSW, System kancelaryjny - przepisy prawne, akta bieżące, sprawa nr AUKSW-040 ${ }^{13}$ Pismo dyrektora administracyjnego UKSW o przeprowadzeniu szkolenia kancelaryjnego AUKSW, Szkolenie pracowników, akta bieżące, sprawa nr AUKSW-14-1/01. 
rektora UKSW z dnia 16 stycznia 2002 r. ${ }^{14}$ Rok później Archiwum przeprowadziło zmianę Regulaminu udostępniania zasobu, precyzując zasady wydawania akt osobowych byłym studentom oraz osobom przez nich upoważnionym. Do tej pory obowiązywała zasada, iż dokumenty wydawane są ,najbliższej rodzinie" na podstawie notarialnie potwierdzonego upoważnienia. Przestrzeganie tej zasady trudno było wyegzekwować, a kłóciła się ona $\mathrm{z}$ rozpowszechnioną praktyka wydawania przez sekretariaty wydziałów akt osobowych byłych studentów osobom przez nich wskazanym, często dyrektorom ośrodków zamiejscowych UKSW. W zwiazku z tym, nie chcąc łamać prawa, a jednocześnie unikając walki z wiatrakami, jaką byłaby próba zmuszenia sekretariatów wydziałów do odstapienia od dotychczasowej praktyki, w nowym Regulaminie zawarto stwierdzenie, iż na wniosek byłego studenta jego dokumenty osobowe mogą być wydane innym osobom na podstawie pisemnego upoważnienia, zwierającego potwierdzenie autentyczności podpisu osoby upoważniającej, dokonane przez uczelnię, organ administracji publicznej lub notariusza ( $(15$ pkt 2 ). Nowy Regulamin udostępniania zasobu Archiwum wszedł w życie 29 listopada 2002 r. $^{15}$

Tymczasem w 2001 r. skomplikowała się sytuacja prawna Archiwum, wskutek wydania przez władze uczelni nowych aktów prawnych, wprowadzających wzajemnie sprzeczne rozwiązania w kwestii organizacji i miejsca Archiwum w strukturze UKSW. Ciagle obowiazujące Zarządzenie nr 7/2000 Rektora UKSW z 1 września 2000 r., tworzące Archiwum jako jednostkę pozawydziałową, podległa prorektorowi ds. rozwoju i współpracy, zgodne z również obowiązującą Instrukcja archiwalna, znalazło się w sprzeczności z postanowieniami Statutu UKSW, wprowadzonego uchwałą Senatu UKSW z dnia 26 kwietnia 2001 r. W Statucie tym znalazł się bowiem zapis, przeniesiony żywcem ze Statutu ATK, iż: Z Biblioteką Główna jest złączone archiwum, które stanowi ogniwo państwowej sieci archiwalnej" (Rozdział 5, $\S 64$, pkt 3$)^{16}$. Powstałą sprzeczność zauważono zbyt późno, gdy Statut został już odesłany do Ministerstwa Edukacji Narodowej w celu jego zatwierdzenia. Tymczasem kolejny akt prawny, jakim był Regulamin organizacyjny UKSW, wprowadzony zarządzeniem rektora z dnia 28 sierpnia 2001 r., nie zważając na zapisy w Statucie, powrócił do początkowych rozwiązań prawnych. W § 41. Regulaminu czytamy mianowicie, iż „Zadania i organizacje Biblioteki, Wydawnictwa oraz Archiwum regulują odrębne regulaminy", zaś § 42 wprowadzał schemat organizacyjny UKSW, w którym Archiwum jest podpo-

${ }^{14}$ Zarządzenie nr 1/2002 Rektora Uniwersytetu Kardynała Stefana Wyszyńskiego w Warszawie z dni 16 stycznia 2002 r. w sprawie ustalenia jednolitego rzeczowego wykazu akt, AUKSW, Wykaz akt, akta bieżace, sprawa nr AUKSW-042-1/02.

${ }^{15}$ Wprowadzała go Decyzja nr 13/2002 Rektora Uniwersytetu Kardynała Stefana Wyszyńskiego w Warszawie z dnia 29 listopada 2002 r. w sprawie Regulaminu udostępniania zasobu Archiwum UKSW, AUKSW, Organizacja jednostek pozawydziałowych - Archiwum, akta bieżące, sprawa nr AUKSW-0121-2/02.

${ }^{16}$ Statut UKSW, wprowadzony uchwałą Senatu UKSW nr 12/2001 z dnia 26 kwietnia 2001 r. w sprawie statutu Uniwersytetu Kardynała Stefana Wyszyńskiego w Warszawie, wydany drukiem jako Statut Uniwersytetu Kardynała Stefana Wyszyńskiego w Warszawie, Warszawa 2001. rządkowane bezpośrednio prorektorowi ds. rozwoju i współpracy ${ }^{17}$. Zgodnie z tymi postanowieniami Regulaminu organizacyjnego UKSW opracowany został omówiony wcześniej - Regulamin Archiwum UKSW, przywracający w kwestii miejsca Archiwum w strukturze uczelni w całej rozciągłości postanowienia Zarzadzenia nr 7/2000 Rektora UKSW o utworzeniu Archiwum. Przypomnijmy, iż Regulamin Archiwum odwołuje się zarówno do Statutu UKSW, jak i do sprzecznych z nim Regulaminu organizacyjnego UKSW i Instrukcji archiwalnej. Sytuacji nie wyjaśniło też kolejne zarzadzenie rektora, z dnia 2 września 2002 r., w sprawie określenia szczegółowego zakresu działania rektora i prorektorów, które zmieniało podległość Archiwum i przekazywało je prorektorowi ds. ogólnych i badań naukowych bez anulowania zapisu o dotychczasowej podległości prorektorowi ds. rozwoju i współpracy oraz zmiany w schemacie organizacyjnym UKSW ${ }^{18}$ Dodajmy na zakończenie rozważań na temat statusu prawnego Archiwum UKSW, iż wobec wytworzonego w ten sposób chaosu kompetencyjnego, Archiwum zgodnie z wieloletnią tradycją ATK - znalazło się de facto w gestii dyrektora administracyjnego. To rozwiązanie zapewniło sprawne funkcjonowanie Archiwum pomimo jego niejasnej sytuacji prawnej. Dzięki nowemu dyrektorowi administracyjnemu, Markowi Lepie, w styczniu 2002 r. Archiwum uzyskało wreszcie pomieszczenie biurowe o powierzchni $7,50 \mathrm{~m}^{2}$. Co prawda nadal brakowało czyteln i udostępnianie akt osobom z zewnątrz odbywało się w biurze Archiwum, ale wobec niewielkiej liczby odwiedzajacych nie stanowiło to większej uciążliwości $^{19}$. Również przy poparciu dyrektora administracyjnego Archiwum przeprowadziło w lutym 2004 r. jedenaście wizytacji jednostek organizacyjnych UKSW. Wizytacje te wykazały na ogół poprawne funkcjonowanie systemu kancelaryjnego, lepsze nawet, niż oczekiwano. Wiązać to należy - jak się zdaje - z dosyć intensywną akcją informacyjną, przeprowadzaną na bieżąco przez pracowników Archiwum oraz ciagle niewielka liczba pracowników administracji UKSW, która pozwala Archiwum ,ogarnąć” sprawy uczelni.

Pomimo istniejących trudności, Archiwum niemal od samego początku starało się wypełniać swoje zadania w zakresie współpracy z archiwami państwowymi i szkół wyższych. Współpracę tę zainicjował udział w spotkaniu archiwistów koś-

17 Regulamin organizacyjny UKSW, wprowadzony Zarządzeniem nr 19/2001 Rektora Uniwersytetu Kardynała Stefana Wyszyńskiego w Warszawie z dnia 28 sierpnia 2001 r. w sprawi wprowadzenia regulaminu organizacyjnego Uniwersytetu Kardynała Stefana Wyszyńskiego w Warszawie; wydany drukiem jako Regulamin organizacyjny Uniwersytetu Kardynała Stefana Wyszyńskiego w Warszawie, Warszawa 2001.

${ }^{18}$ Zarządzenie nr 28/2002 Rektora Uniwersytetu Kardynała Stefana Wyszyńskiego w Warszawie z dnia 2 września 2002 r. w sprawie określenia szczegółowego zakresu działania rektora i prorektorów, AUKSW, Organizacja jednostek pozawydziałowych - Archiwum, akta bieżące, sprawa nr AUKSW$0121-1 / 02$.

${ }^{19}$ Dla przykładu: w 2001 r. odnotowano 7 wizyt, w 2002 - 10, w 2003 - 1 (!), ale już w 2004 r. -13. Szerzej na ten temat zob. D. Milewski, Udostepnianie materiałów archiwalnych $w$ Archiwum UKSW - zasady i praktyka, w: Archiwa i ich użytkownicy. XV Konferencja Naukowa Sekcji Archiwów Szkól Wyższych, Instytucji Naukowych i Kulturalnych Stowarzyszenia Archiwistów Polskich Katowice, 21-23 czerwca 2007 r., red. A. Krzemińska, Warszawa 2007, s. 93-97. 
cielnych 18 czerwca 2002 r. w Warszawie. Począwszy od następnego roku, Archiwum brało udział w pracach Sekcji Archiwów Instytucji Kulturalnych i Naukowych Stowarzyszenia Archiwistów Polskich, co wyrażało się przede wszystkim w uczestnictwie przedstawicieli Archiwum w konferencjach naukowych, organizowanych m.in. przez tę Sekcję. Można tu wymienić następujące konferencje: „Kategoria archiwalna akt” (Łódź 2003), „Archives and Changing Societies Active Strategies for Meeting Public, Institutional, and Archival Needs" (Warszawa 2003, konferencja zorganizowana przez International Council on Archives, Section of University and Research Institution Archives), „Archiwum jako wizytówka macierzystej instytucji” (Poznań 2004), „Znaczenie dokumentacji i archiwum w działalności szkoły wyższej” (Koszalin 2006, konferencja zorganizowana przez Politechnikę Koszalińska), „Archiwista w instytucji naukowej” (Legnica 2006), „Archiwa i ich użytkownicy” (Katowice 2007), „Dokumentacja nieaktowa w instytucjach nauki i kultury” (Kielce 2008) oraz „Jubileusz 60-lecia Archiwum Uniwersytetu Mikołaja Kopernika w Toruniu (1948-2008)" (Toruń 2008). Zadbano również o zapoznanie społeczności Uniwersytetu z owocami tych konferencji poprzez publikowanie sprawozdań na łamach czasopism naukowych Wydział Nauk Historycznych i Społecznych UKSW20.

Negatywne skutki dla działania Archiwum miało natomiast okresowe przydzielenie jego pracownikom dodatkowych obowiazków w zakresie bezpieczeństwa i higieny pracy oraz ochrony informacji niejawnych ${ }^{21}$. Wiązało się to poniekąd $\mathrm{z}$ niezrozumieniem znaczenia Archiwum dla Uniwersytetu, zarówno jako koordynatora obiegu kancelaryjnego pism, jak i skarbnicy pamięci. I o ile udało się pracownikom Archiwum przekonać wreszcie większość pracowników registratur do użyteczności bezdziennikowego systemu kancelaryjnego, o tyle po wszechna opinia o tym, iż ,w Archiwum nie ma nic do roboty", pozostaje trudna do wykorzenienia. Jeśli już bowiem nawet wiedza o tym, iż archiwiści zajmują sie porządkowaniem i opracowaniem akt, dociera do społeczności Uniwersytetu, to $\mathrm{i}$ tak zajecie to doceniaja jedynie pracownicy naukowi i to $\mathrm{z}$ reguły tylko historycy, którzy korzystają ze zbiorów Archiwum. Dla całej reszty „opisywanie starych papierów" nie ma najmniejszego sensu. W tej sytuacji nie dziwi fakt, iż pracownikom Archiwum postanowiono dać dodatkowe obowiązki, aby zajęli się wresz-

${ }^{20}$ Zob. D. Milewski, Sprawozdanie ze spotkania archiwistów kościelnych $w$ Warszawie 1 czerwca $2002 r$., Saeculum Christianum" (dalej: SC), 9 (2002), nr 2, s. 319-322; Tenże, Sprawozdanie z konferencji Sekcji Archiwów Instytucji Kulturalnych i Naukowych w Lodzi 10-11 czerwca 2003 r. Tamże, SC, 10 (2003), nr 1, s. 281-284; Sprawozdanie z X konferencji Sekcji Archiwów Szkót Wyższych i Instytucji Naukowych SAP w Poznaniu, 24-25 czerwca 2004 r., SC, 11 (2004), nr 2, s. 299-304: Sprawozdanie $z$ konferencji naukowej «Znaczenie dokumentacji $i$ archiwum $w$ dzialalności szkoty wyższej». Koszalin 27-28 IV 2006 r., SC, 13 (2006), nr 2, s. 301-305; R. Poletyło, Sprawozdanie z konferencji naukowej «Jubileusz 60-lecia Archiwum Uniwersytetu Mikolaja Kopernika w Toruniu (1948-2008)», Toruń, 10 października 2008 r., ,Zeszyty Naukowe Wydziału Nauk Historycznych i Społecznych UKSW. Historia", 1 (2009) [w druku].

${ }^{21}$ Młodszy dokumentalista Adam Stepień został w listopadzie 2003 r. mianowany inspektorem ds. BHP, zaś Dariusz Milewski powołany został z początkiem stycznia 2004 r. na pełnomocnika rektora ds. ochrony informacji niejawnych. cie „czymś pożytecznym”. Zmiana tego stanu rzeczy nastapiła dopiero w latach 2007-2008, kiedy to zdecydowanie poprawiła sie sytuacja lokalowa Archiwum, a po zmianach kadrowych archiwiści - w częściowo nowym składzie - powrócili do swych właściwych zadań. Tematyka ta wiąże się już jednak z bieżącą działalnością Archiwum i wykracza poza ramy tego studium.

\section{THE FIRST YEARS OF THE ARCHIVE OF THE CARDINAL STEFAN WYSZYŃSKI} UNIVERSITY IN WARSAW - ORGANIZATION AND FUNCTIONING

Summary

The article is devoted to the creation and the first period of activity of archive of the Cardinal Stefan Wyszyński University in Warsaw. The Catholic Academy in Warsaw archived its documentation in particular registry offices. The change took place with the creation of the Archive of UKSW in 2000 . The article describes the circumstances of the creation of the Archive and its legal foundation. It also presents the development of the position of the Archive in the university structure in view of university legal acts and practice. The current activity of the archives is also discussed, the causes of the initial problems are analysed and the development perspective is indicated.

Translated by Agnieszka Kędzierawska 